
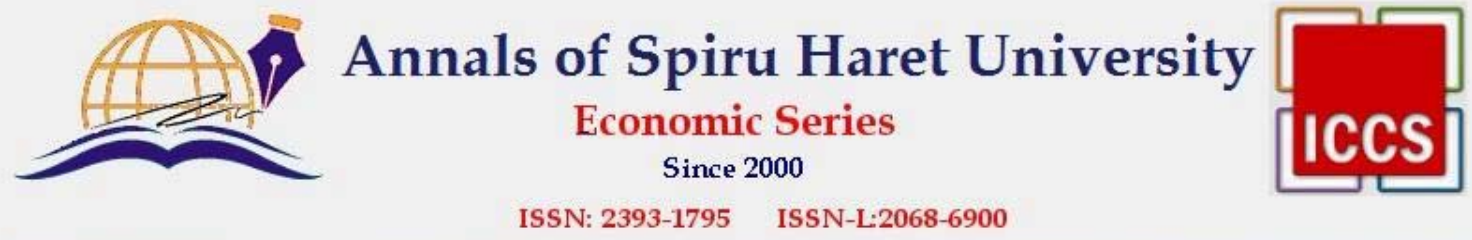

Issue 2/2016

\title{
TOWARDS 2030 AND MORE: DESIGNING A SUSTAINABLE FUTURE
}

\author{
Larisa MIHOREANU ${ }^{1}$, Alexandru ȘTEFĂNESCU ${ }^{2}$, Adrian VASILE ${ }^{3}$, \\ Carmen COSTEA ${ }^{4}$ \\ 1,2,3 Academy of Economic Studies, 6 Piața Romană, Bucharest, Romania, \\ Email:mihoreanu@spiruharet.ro,dr.alexstefanescu@yahoo.com, \\ adrian.vasile777@yahoo.com \\ 4 "Spiru Haret" University, Ion Ghica Street, no. 13, Bucharest, 030045, \\ Romania, Tel.: +40214551000, Fax: +40213143900,
}

Email: cecostea@yahoo.com

\begin{abstract}
Global development is not only a strategy, a practice, or a process. It is also a perception linked to mental constructs and desiderates, a place to reinvent living and doing business. No matter the topic of it-social, economic, environmental, the single approach will never be enough.

Changes in global development issue aggressive challenges of competition and uncertainty for market, society and individuals at a local level which impact more widely than expected described by complex systems science as the "butterfly flapping" effect influencing development in all its dimensions. The change comes along with opportunities, risks and challenges, which influence both life and work.

In the present paper, we combat the myth of "no choice" policy and sustain the recovery of the fundamental values by exploring new approaches to the relationship between governments, markets, society and environment.
\end{abstract}

Key words: global development; change; competition; modern cities; smart transportation.

JEL Classification: O05, O012 


\section{Annals of Spiru Haret University \\ Economic Series \\ Since 2000 \\ ISSN: 2393-1795 ISSN-L:2068-6900}

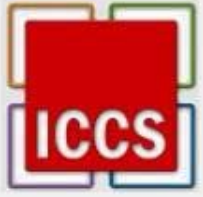

Issue $2 / 2016$

\section{Introduction}

The actual perception about globalization widely regards it as an irreversible and developing affair from a western tale to a universal experience.

The emerging BRICS countries ${ }^{1}$ powers are on their way to tremendously increase contribution in terms of labour force, applied new technologies and even a new vision of life issued from both Western and Eastern ancient experiences.

There are powers still questioning about the way the fragile democracies based on billions of underpaid hard-workers can challenge the status quo of the Western life style and thinking patterns.

One of them is the Market.

No matter the political decision, the markets chose to merge globally [Cretoiu, 2014]; therefore, the consumer becomes global [Gârdan \& Geangu, 2015]. he sharing?

But how is the global consumer's thinking like? What life values is

\section{Can Human Rationalism Survive Alone?}

Today's world looks dominated by the Western society's thinking patterns.

Whether today biggest brands in the world speak about people's car, to refresh the world or ideas for life, they are the expression of the Occidental values and philosophy.

They are the expression of the Western welfare capitalism or welfare state models and Western rationalism, although rationalism and rationalization have previously existed not only in the modern West but in all great civilizations [Schkuchter, 1981].

Therefore, this global rational seed has given birth to the actual global knowledge tree, which offers to consumers its irresistible fruits: the global brands.

${ }^{1}$ Brazil, Russia, India, China, South Africa. 


\section{Annals of Spiru Haret University \\ Economic Series \\ Since 2000 \\ ISSN: 2393-1795 ISSN-L:2068-6900}

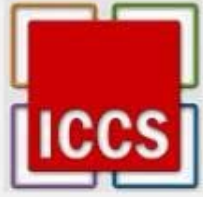

Issue $2 / 2016$

Brand competitiveness has already become a benchmark for corporations' ability to drive profits - the most common and rationale way to assess the value of the new economy businesses [Bondrea et al., 2014].

Until now, the current accepted forms of the new economy considered the economic correlations - figures linked to GDP, the number of computers and mobile phones number and so on.

People are now looking for more important answers linked to fundamental questions, about the quality and the value of their work and life, for example.

Once the answers found, they will generate other questions and discover new approaches of what the societal responsibility should be and our awareness and engagement should cover to sustain collective results and value the socio-economic efforts.

This comes within a new historical context of work and life, where:

a) the switch towards a new dimension of the perfect digitalised market may provide not only profits but better general quality;

b) the provoked increasing of economic and social competitiveness and ceaseless of the financial crisis outline by the money transformation;

c) the current demographic conjuncture aggregates the health depreciation, in case that the world command will remain in the same hands.

People are influenced, besides multiple other factors, by their environment conditions. An inappropriate, hostile environment (noise, pollution, unbalance diet, disconnection from the nature, etc.) will induce the development of appropriate defensive psychophysical mechanisms.

As a result, building a better society could help the psychophysical health to improve.

The mechanism will not be conditional anymore of the attributes of age but the positive stimulus will come from the satisfaction of life and work.

There are findings showing that the defensive exposure of individuals was found previously as a result of long-term effects of environmental noise [Iwata, 1980]. 


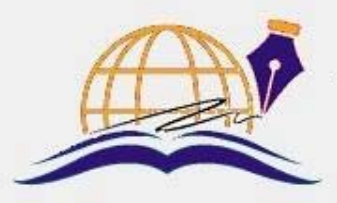

Annals of Spiru Haret University

Economic Series

Since 2000

ISSN: 2393-1795 ISSN-L:2068-6900

Issue 2/2016

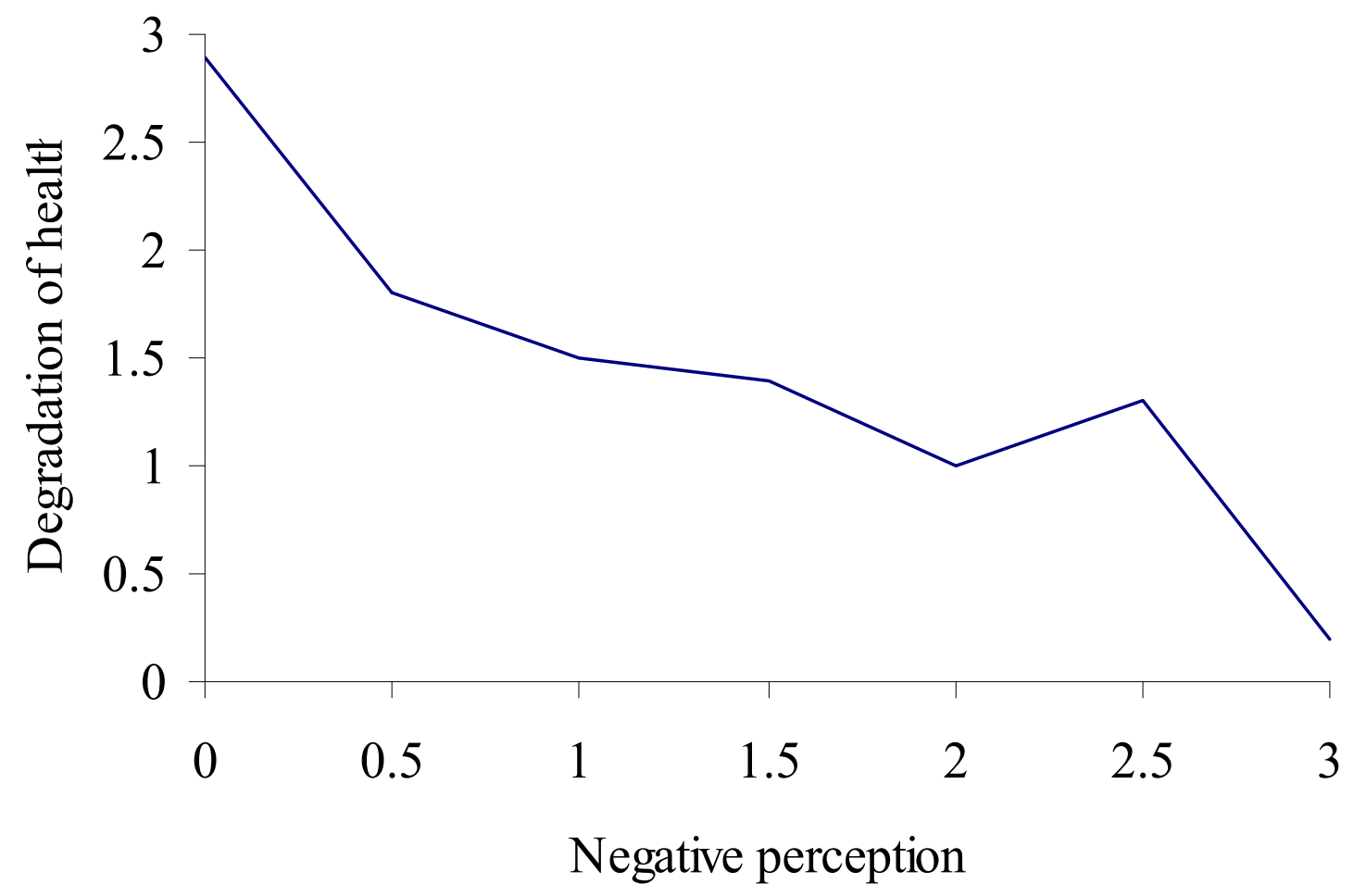

Figure no. 1. The negative perception of pollution against the psychophysical health degradation

Source: Iwata, O. (1980) in Kazi Saifuddin, Md. Zahir Uddin Arif, Md. Nazmul Ahsan Khan, (2009), Psychophysical Health in relation with Environmental - Noise Perception Working Paper, Gazipur, Bangladesh

The persisting labour market vulnerabilities and imbalances skills provided by the today employees have prevented emerging countries to fully benefit from the international dynamics.

The limits of the legal economy caused by bureaucracy and lack of full implementation of laws, methodologies and regulations have been doubled by the strong dynamics of the informal economy and its flexible adjustment to change kept the developing countries away from integration into the world recognized economy. 

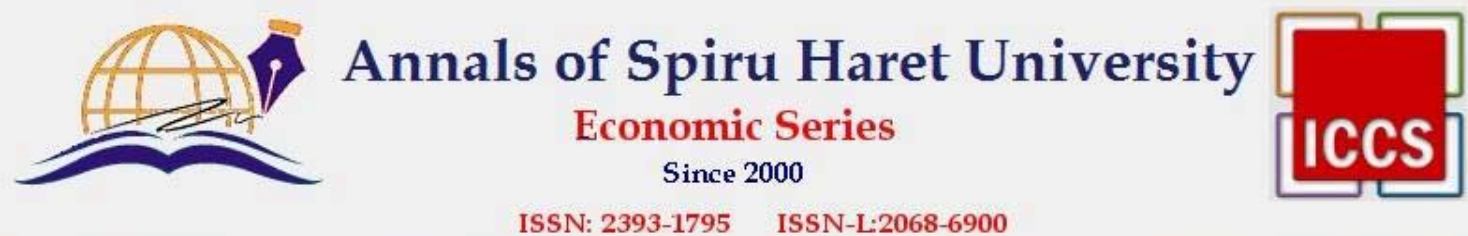

Issue 2/2016

Even more, the large informal economies kept the small or emerging countries aside the sound development through increased exportations and high performance.

The underperformance of our society in regard to corruption, lack of performance, immature management and social stress are enough reasons to consider the need for a change.

The business excellence and the high profits come not only from robbery and industry dismantle; it can be obtained if a fine analyse will be considered and the sound change implemented.

The continuous run after competitiveness will depend much more on the ability of various organizations and states to attract and to develop highly adequate skilled labour force. Employees will work with more satisfaction if they have access at an open program and their work will be assessed objectively.

Table no. 1. Characteristics of the legal sector and informal circuit in the emerging countries

\begin{tabular}{|l|l|l|l|}
\hline \multicolumn{1}{|c|}{ Indicators } & \multicolumn{1}{|c|}{$\begin{array}{c}\text { Legal } \\
\text { Economic } \\
\text { Movements }\end{array}$} & \multicolumn{1}{|c|}{$\begin{array}{c}\text { Informal/ } \\
\text { Hidden Circuits }\end{array}$} & \multicolumn{1}{|c|}{$\begin{array}{c}\text { Needs } \\
\text { to Changing } \\
\text { the Future }\end{array}$} \\
\hline IT programs & $\begin{array}{l}\text { Capital } \\
\text { investment }- \\
\text { intensive }\end{array}$ & Labour intensive & $\begin{array}{l}\text { Capital and labour } \\
\text { intensive }\end{array}$ \\
\hline Organisation & $\begin{array}{l}\text { Excessive } \\
\text { Bureaucratic }\end{array}$ & $\begin{array}{l}\text { Worthy of reliance but } \\
\text { archaic approach }\end{array}$ & $\begin{array}{l}\text { Performing } \\
\text { management }\end{array}$ \\
\hline Capital & Handy & $\begin{array}{l}\text { Limited funds, limited } \\
\text { access }\end{array}$ & $\begin{array}{l}\text { Legal placed } \\
\text { investment }\end{array}$ \\
\hline $\begin{array}{l}\text { Labour and regular } \\
\text { wages }\end{array}$ & $\begin{array}{l}\text { Prevailing } \\
\text { limited }\end{array}$ & Ample & $\begin{array}{l}\text { Competences \& } \\
\text { realistic assessed } \\
\text { skills }\end{array}$ \\
\hline Equipment & $\begin{array}{l}\text { Large quantity/ } \\
\text { Inappropriate } \\
\text { use or quality of } \\
\text { goods } \\
\text { (sometimes) }\end{array}$ & $\begin{array}{l}\text { Few with } \\
\text { the right quality }\end{array}$ & $\begin{array}{l}\text { Patterned } \\
\text { equipment } \\
\text { Externalisation }\end{array}$ \\
\hline Reuse of goods & Quite rare & Often & Often \\
\hline
\end{tabular}



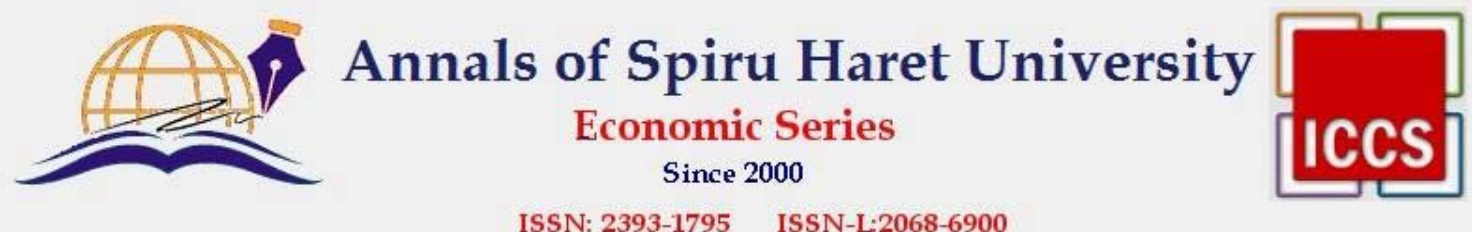

ISSN: 2393-1795 ISSN-L:2068-6900

Issue 2/2016

\begin{tabular}{|c|c|c|c|}
\hline Indicators & $\begin{array}{c}\text { Legal } \\
\text { Economic } \\
\text { Movements }\end{array}$ & $\begin{array}{l}\text { Informal/ } \\
\text { Hidden Circuits }\end{array}$ & $\begin{array}{c}\text { Needs } \\
\text { to Changing } \\
\text { the Future }\end{array}$ \\
\hline Fixed costs & Large & Small & Small \\
\hline Price & Fixed & Negotiable & Negotiable \\
\hline Loans & Institutional & $\begin{array}{l}\text { Personal, chosen } \\
\text { institutions }\end{array}$ & $\begin{array}{l}\text { Adequate } \\
\text { institutional and } \\
\text { private }\end{array}$ \\
\hline $\begin{array}{l}\text { Turnover/Expected } \\
\text { profit }\end{array}$ & Large/Excessive & Small/Large per unit & Large per unit \\
\hline $\begin{array}{l}\text { Relations with } \\
\text { customers }\end{array}$ & $\begin{array}{l}\text { Cold, } \\
\text { impersonal }\end{array}$ & Trustful/Personalised/Direct & $\begin{array}{l}\text { Trustful/ } \\
\text { Personalised/Direct }\end{array}$ \\
\hline Advertency & $\begin{array}{l}\text { Large } \\
\text { amounts/Less } \\
\text { creativity }\end{array}$ & Hidden & Modern methods \\
\hline Government aid & Substantial & Indirect existence & $\begin{array}{l}\text { Orientation } \\
\text { towards } \\
\text { multilateral } \\
\text { sustaining }\end{array}$ \\
\hline External aid & $\begin{array}{l}\text { Orientation } \\
\text { towards } \\
\text { multilateral } \\
\text { sustaining }\end{array}$ & Almost inexistent & $\begin{array}{l}\text { Orientation } \\
\text { towards } \\
\text { multilateral } \\
\text { sustaining }\end{array}$ \\
\hline
\end{tabular}

Source: processed after Pacione, Urban Geography: A Global Perspective, p. 478

States and organisation will be obliged to take into account the traditional aspects of living values, as they were and should be. The fundamental values will shape the new world and should become the roots of the new values of the future world economy.

Statistics show that nowadays the individuals' beliefs are more and more important for the economic development and the flourishing democratic activity of local and international entities.

Individuals' beliefs and behaviours are the bottom line of gender equality recognition and appreciation and the extent to which societies build and govern effective political management and organizations. Thus, the global mutations identify the new localizations and scores of societies given the cultural bi-dimensions considered: the role of traditional values underlining the secular ones, while the survival values make spring the selfexpression ones. 

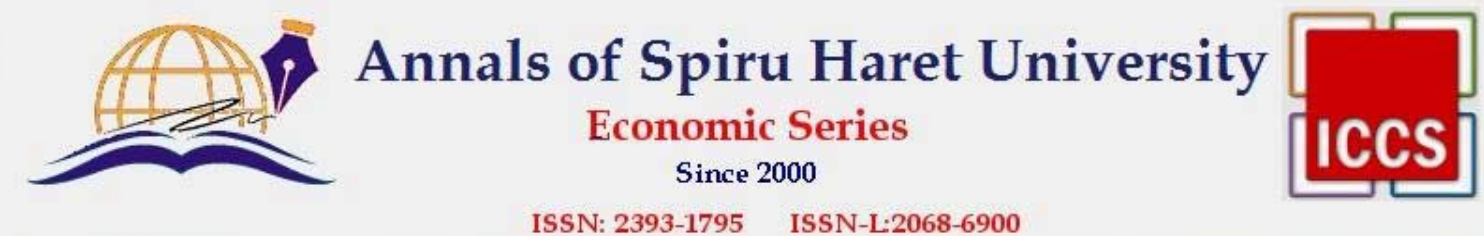

Issue 2/2016

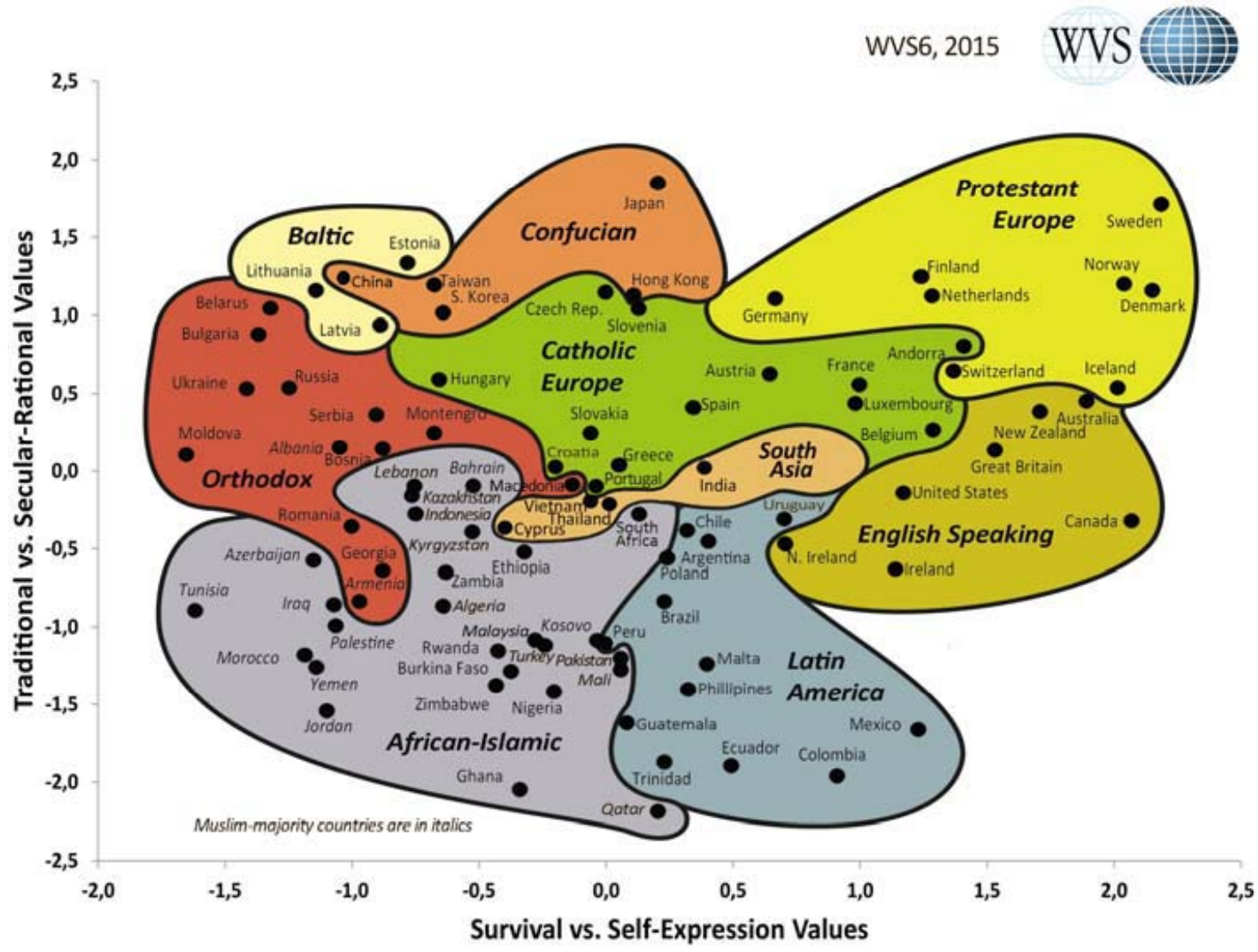

Figure no. 2 Survival vs. Self Expression Values

Source: http://www.worldvaluessurvey.org/images/Cultural_map_WVS6_2015.jpg

The global economy depends now heavily on human expertise from cabinet staffers to civil servants. Nongovernmental actors are becoming more and more powerful and now they influence policy making processes in all aspects of social life and economy. Think-tanks, regarded by many scholars as elite organizations being able not only to influence but also to formulate and envisage policies and strategies at global level [Donald E. Abelson,2002], are becoming more and more involved into shaping global directives. It has to be seen if they would become policy instruments or they would evolve to rational policy elites able to carry global governance. Nevertheless the extent to which global governance can influence change in a positive manner is fiercely debated. Could it be transparent enough not to 


\section{Annals of Spiru Haret University \\ Economic Series \\ Since 2000 \\ ISSN: 2393-1795 ISSN-L:2068-6900}

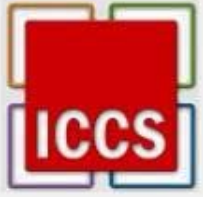

Issue $2 / 2016$

cover corruption and dictatorship, wise enough not to favour social and economic polarization and furthermore social wars? The virtual landscape of tomorrow is promising a new era in which the human rationalism may no longer survive alone; it could need the human spirit aside, together with its real values of which actual configuration is so weak.

\section{Analysing the Society as a Complex Living Logistics}

As an economic concept, logistics is more than a field widely connected to any sector of economy and society - that transformed dramatically in the last years. Although this science is coming a long way from the past, the basic of this activity stayed the same: transport and delivery of objects, goods from source to destination. The special characteristic of this domain that makes it special for the human beings and the economy advance is the analogy with any organic material. The structure is the same, but the environment is so dynamic that is determined to modulate according to the on-going transformations (climate changes, human print and society evolution and transformation).

The changes are not only about technologies and population. The changes are connected to emerging countries borders, to fast growth and stable future. According to HSBC Report the following countries will grow in the fastest way: China, India, Philippines, Egypt, Malaysia, Peru, Bangladesh, Algeria, Ukraine, Vietnam, Uzbekistan, Tanzania, Kazakhstan, Ecuador, Ethiopia, Sri Lanka, Azerbaijan, Kenya, Bolivia, Jordan, Uganda, Ghana, Paraguay, Turkmenistan, Honduras, and Serbia. It could be challenging to imagine this transformation for the next 20-30 years.

In this respect, the latest projects presented at VisionWorks Award might give us a glance in the future:

- Mobile Pack station is a concept consisting of a Mobile Device and a Package Device. The latter organizes and sorts the RFID-tagged packages. The mobile device is the servant and provides the delivery service. It has four bumpers and can use the tram transport system. At a tram station the device disconnects from the rails and moves by itself into residential zones. As the mobile parcel deposit and pick-up module can park in parking zones, next to public buildings, shopping centres or simply on the sidewalk, 

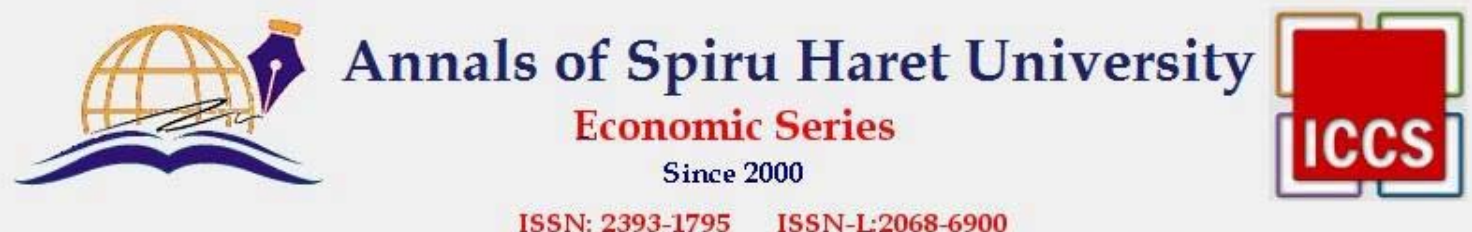

ISSN: 2393-1795 ISSN-L:2068-6900

Issue 2/2016

permanent stations are not required. A mobile solution also has less impact on the townscape. The client identifies himself by his mobile phone, cylinder turns to get the right package in front, the cover opens and the client can take his package out;

- Underground Distribution System (UD) refers to the use/movement of subway trains for delivering goods over the last mile subways terminals locations being outside the city centre, they are accessible and may lead to less traffic or parking problems. Equipped with mobile robots, the cargo wagon may enable automatic loading and unloading and the packages can travel by with the train to the right destination where the robot unloads them. Finally the customer goes to the nearest subway station to pick up his delivery;

- The Multibarge Ship Atlas is a cargo ship able to transport barges already loaded with containers. The vessels have the bridge deck in the proximity of the bow as they have to load the barges from the stern. The Multibarge Ship reaches the harbour and, under a fast immersion, enables the loaded barges to slide inside it. The system is much quicker and the project is more efficient than a traditional cargo ship;

- CargoGuard is a reusable packing system for load protection on a palette. Its special feature relies on the net electro-active polymers content that can expand by up to $380 \%$ of its normal size under voltage. After covering the load with the net foil which has to be extended by a voltage input, the net foil simply has to be fixed by loops on the palette. After removing the energy, the net foil shrinks to its normal size, thereby stabilizing the load on the palette. The system enables the load to be secured against theft by special security codes preventing the energy supply from being activated by using inadequate devices;

- The Urban Mole acts as a postal agent acting inside the city and deliver packages based on sewers as a new-old infrastructure. The mole itself is a mobile unit food goods and merchandises, able to identify and use it on way to destination. Nevertheless, this is only the techno-economic side of the future to come. The most important one is linked to people, their perceptions, beliefs, their awareness of working and getting engaged into the deep and revolutionary transformation of the mankind together with their cities. Therefore the mankind should be addressed as the most important element of the intelligent logistic network of the future world. 


\section{Annals of Spiru Haret University \\ Economic Series \\ Since 2000 \\ ISSN: 2393-1795 ISSN-L:2068-6900}

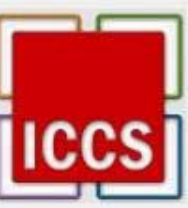

Issue $2 / 2016$

The cities of tomorrow, if they decide to remain on the world map of megacities, will be obliged to handle the daily traffic by transforming their location and link them to the smart logistics utilities accepting the intelligent modules of connection for transit, connection, transferrals, shipping, transportation, and expatriation.

At European level, the new recommendations and strategies are already settled on the new roadmap of this future smart logistic policy. The forecast on the European Union triple budget in the transportation sector, takes into consideration a new core network, defined to provide personalised full trajectories and eliminate the bottlenecks, and avoid any losses from delays. Modern infrastructures with open access to new transportation corridors will create vivid clusters where all agents from the single market countries will get better working results and use more efficiently both resources and human capital. The smart logistics should be able to use the so called urban moles in providing all sorts of services: cargo transportation, international trade, military and emergency, medical and paramedical, volunteering. The access could be open via individual access authentication, personalised labels, prepaid codes, institutional encapsulated chips. The systems should be certified to be used safely, in strictly security, and comfortable handling of all logistics information.

The material individual fingerprint is any one of the eight corners, so no extra code, no print and no polluting chip has to be searched [www.visionmarketaward.com]. Work on such researches is running but better solutions are checked as potential alternatives to everyday problems: pollution, traffic, environment and individual protection. This means that individuals will become the core of any logistic systems and, from this point of view has to insight new treats to the daily living and working comfort.

Once accepted as valid, such solutions will create the premises to a durable social and technological development that will enable human society growth and it will lead to the right way.

The development of logistics by introducing the concept of intermodal transport which involves connection and simultaneous use of several types of transport has important position benefits both environmental and economic; this can have also important applications in 


\section{Annals of Spiru Haret University \\ Economic Series \\ Since 2000 \\ ISSN: 2393-1795 ISSN-L:2068-6900}

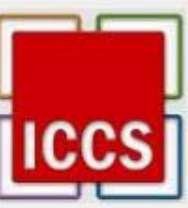

Issue $2 / 2016$

other departments and sectors of human life. Used inside the cities, the urban transport will undergo important changes which will lead to winning employees time - on their way to or from work - that can be dedicated to education, health care and prevention, entertainment.

The use of intermodal transport could be useful in the health care management system too. Multi-modal terminal operators can ensure that the delivery time of any medical load that can be solved with alternative plans. The transit time clearly expressed by patients, medicines and equipment, health monitoring along the route are other advantages of combining medical transport services. Also, "qualities" are the modules and the lack of traffic jams, but also greatly reduced risk in the transport of highly damaged patients or highly sensitive transports life human organs. Moleculised emergency departures, for hospitals, medical care or pharmaceutical companies could become the perfect choice inside the new path of modernisation of medical market.

From the perspective of territorial approach any exercise of analysis and spatial planning should target a clearly defined perimeter study, in order to establish objectives and priorities for the territory. The limitation of the territory among the criteria detained are local influences noticeable in consideration to a modernised logistic structure and typology of medical activities and incorporating them into the architecture socio-economic local designing a ways necessary logistical and calculating economic impact through its integration into local infrastructure existence, population structure.

As a first step it is necessary to identify the aerials and poles that will be part of the logistics network beyond the existing active emergency systems that sometime prove themselves in operational. These poles should be analysed as a polycentric network, considering the dramatic demographic changes of the moment, the future of the areas and especially the sensitivities of the local population and their socio-economic and financial portrays. Education and democracy are and will be important for the sustainable development; but more important it will be the implement of new models to size the performances on how productive each individual will be. We need also considering how many they will be remaining in the countries of origin. 

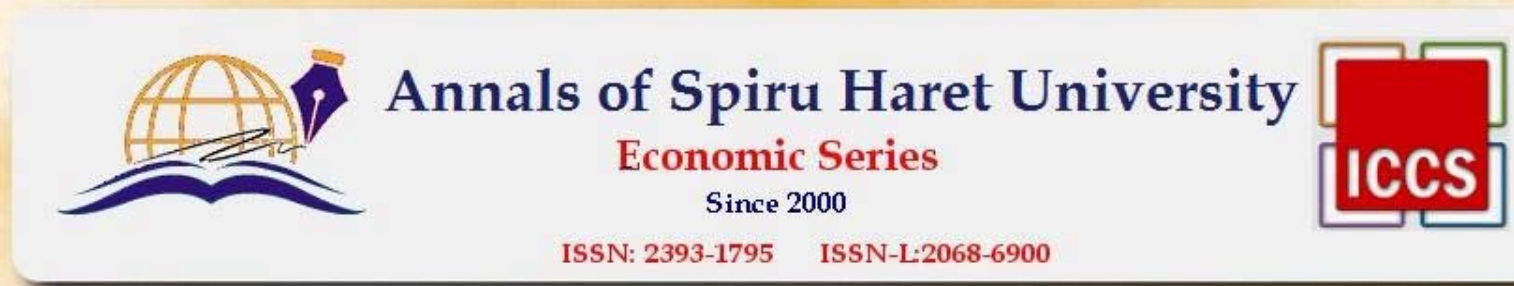

Issue 2/2016

Table no. 2. Projections for total GDP after The World in 2050 HSBC Report

\begin{tabular}{|l|l|l|l|l|}
\hline $\begin{array}{l}\text { Central \& Eastern } \\
\text { Europe }\end{array}$ & $2010-$ & $2020-$ & $2030-$ & $2040-$ \\
2030 & 2040 & 2050 \\
\hline Belarus & $5.2 \%$ & $4.3 \%$ & $3.9 \%$ & $3.0 \%$ \\
\hline Bosnia \& Herzegovina & $6.7 \%$ & $5.2 \%$ & $4.4 \%$ & $3.5 \%$ \\
\hline Bulgaria & $3.6 \%$ & $3.7 \%$ & $3.3 \%$ & $2.8 \%$ \\
\hline Croatia & $3.8 \%$ & $3.4 \%$ & $3.3 \%$ & $2.8 \%$ \\
\hline Cyprus & $3.7 \%$ & $3.2 \%$ & $3.3 \%$ & $2.9 \%$ \\
\hline Czech Republic & $4.6 \%$ & $4.4 \%$ & $3.6 \%$ & $2.7 \%$ \\
\hline Hungary & $4.7 \%$ & $4.7 \%$ & $3.9 \%$ & $3.2 \%$ \\
\hline Latvia & $4.8 \%$ & $4.2 \%$ & $3.8 \%$ & $2.9 \%$ \\
\hline Lithuania & $3.4 \%$ & $3.0 \%$ & $3.1 \%$ & $2.9 \%$ \\
\hline Poland & $3.3 \%$ & $3.2 \%$ & $3.1 \%$ & $2.1 \%$ \\
\hline Romania & $6.1 \%$ & $5.7 \%$ & $4.3 \%$ & $3.5 \%$ \\
\hline Russia & $4.2 \%$ & $4.0 \%$ & $4.0 \%$ & $3.3 \%$ \\
\hline Serbia & $6.5 \%$ & $5.9 \%$ & $5.1 \%$ & $4.4 \%$ \\
\hline Slovak Republic & $3.7 \%$ & $3.3 \%$ & $3.0 \%$ & $2.2 \%$ \\
\hline
\end{tabular}

Source: Karen Ward (2012) Economics, Global, 11 January 2012

This way, the demographic burdens will switch into individual lucrativeness and added value contribution. Population growth will not be enough to certify the stable growth. Other foundations are necessary to create and ensure jobs and develop the economy. New projections will get closer to build new GDP forecasting if the indicator the income per capita will be based on the economic infrastructure and the number of 'capitas'; this definitely will assure the change in working population. Over the next 40 years, all economies reach the optimal economic infrastructure. If until now the governments assumptions considered improving the underlying economic infrastructure, implementing reform, increasing education and remain friendly with their neighbours the scenario that we have in mind could go beyond of this and create another image of what economic infrastructure could become, such as: 

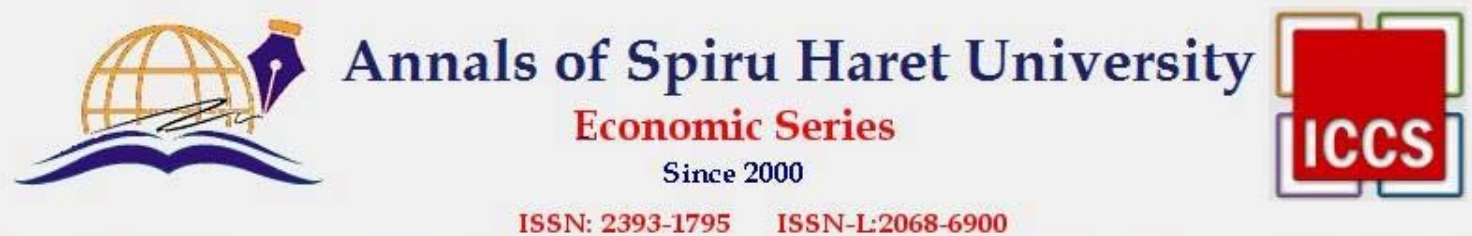

Issue 2/2016

- GDP per capita;

- average years male schooling (education); healthcare;

- life expectancy and fertility (average children per person) market);

- rule of law and government consumption (legal side of socio-

- democracy index (politics);

- inflation rate (finance).

\section{Conclusions}

It would be ideal if it would develop logistics platforms located near intermodal major hubs. From this perspective, a permanent and improving cooperation with neighbouring regional medical care sectors to be incorporated inside these logistic medical platforms can be registered on the wish list for the proper development of an intermodal transportation. Another help could come from extensive integration of medical customs services with combined healthcare hubs to reduce the time to perform formalities. The first step has been done when the decision of building a tunnel ring between Budapest, Bratislava and Vienna was taken. This one will speed not only the cargo and passengers; this will improve the people's access to better conditions of health and durable treatment for society and citizens benefit.

The obvious reason is to understand and use widely intermodal logistics as this relies in larger possibilities of combining advantageously qualities specific to each system included in the new logistics: the flexibility of transportation, the high speed of action of all actors involved, the lower costs and superior speed joined to common sense and purpose of efficiency of government, companies and patients.

Certain high-volatility investments could become topics of discussions and falls in value if they exceed the amount invested. Others could discuss the position of some countries with low conditions and degrees of education that may barely forecast the growth. However, to recalibrate the growth and impact any model of stability, people and specialists should let them surprised by the accuracy of the proposed indicators and the simplicity of implementing them. 


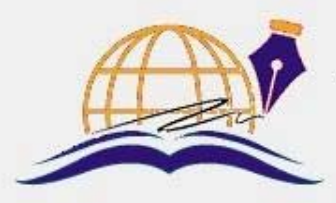

Annals of Spiru Haret University

Economic Series

Since 2000

ISSN: 2393-1795 ISSN-L:2068-6900

Issue 2/2016

\section{References}

1. Abelson, Donald E., Do Think Yanks Matter? Assessing the Impact of Public Policy Institutes (McGill - Queen's University Press, 2002), 23-24.

2. Arif, Zahir Uddin and Khan, Nazmul Ahsan, "Psychophysical Health in relation with Environmental", Noise Perception Working Paper (Gazipur, Bangladesh, 2009).

3. Bondrea, Aurelian et al., Emerging from Crisis with New Approaches to Science of Society (WREMSD, 11(2-3), 2011), 172-185.

4. Crețoiu, Raluca Ionela, "The Complexity of the Implications of Globalization in the Context of the Current Global Economy", Annals of Spiru Haret University, Economic Series (București: Editura Fundației România de Mâine, Vol. 5, Issue 1, 2014), 41-49.

5. Gârdan, Daniel Adrian and Gârdan (Geangu), Iuliana Petronela, "The Social and Economic Factors Influence upon the Healthcare Services Consumers Behaviour", Annals of Spiru Haret University, Economic Series (București: Editura Fundației România de Mâine, Vol. 6, issue 3, 2015), 45-54.

6. Iwata, O., Determinants of Noise Effects. In Noise and Vibration Research Group of Environmental Sciences, Supported by the Japanese Ministry of Education's Grant-in-Aid for Scientific Research in Kazi Saifuddin (1980).

7. Schluchter, Wolfgang, The Rise of Western Rationalism: Max Weber's Developmental History (University of California Press Ltd, Berkeley, USA, 1981), 9.

8. Ward Karen, Economics, Global (New York, 11 January 2012).

9. www.visionworksaward.com/06-participants/bremen/BACS.html. 